\title{
Job Stress among Malaysian Managers: The Moderating Role of Coping Methods
}

\author{
Kumaresan V. Sathasivam ${ }^{1}$, Dr. Mohd Dahlan Hj. A. Malek ${ }^{2}$, \& Prof. Dr. Ahmad Faris Abdullah ${ }^{3}$ \\ ${ }^{1}$ School of Medicine, University Malaysia Sabah, Malaysia. \\ ${ }^{2}$ School of Psychology and Social Work, University Malaysia Sabah, Malaysia. \\ ${ }^{3}$ School of Medicine, University Malaysia Sabah \\ Correspondence: Kumaresan V. Sathasivam, School of Medicine, University Malaysia Sabah, Malaysia.
}

Received: February 6, 2015

doi:10.11114/ijsss.v3i3.742
Accepted: February 25, 2015

Available online: March 24, 2015

\begin{abstract}
Job stress is vastly present in today's organizations, and the costs of these phenomena cut across all levels of society. In recent years, researchers considering job stress in the workplace have made great strides in understanding several aspects of the stress phenomenon in the field of organizational behavior. Thus, it becomes more important that the coping methods of these job stresses are well explored and directly linked to individuals experiencing this situation, in order to ensure the right methods can be used for the best benefits in coping with job stresses. This research presents an integration of past research and theory that models the relationship of antecedents of job stress and coping methods among managers. The scope of this case study is limited to managerial positions in electronics firms in Malaysia. A set of demographic factors like gender, marital status and educational background, are also studied as influencing factors to job stress. The final framework in this study includes the coping variables, in which will determine the best and most suitable coping methods for managers under job stress. A proportional sampling plan will be done to cover the surveys to be covering all major locations of electronics firms in Malaysia. Theoretical and managerial implications of the study will be discussed in details. The implication of the study would be extremely beneficial for electronics organizations in not only identifying the organizational sources of job stress, but also to understand the personality behaviors of their management staffs. More importantly, this study will recommend the best coping methods for managers that would enable the leadership team in the electronics organizations to be able to handle job stress more efficiently.
\end{abstract}

Keywords: Job stress, coping methods, managers, electronics industry, cognitive, social and emotional 1. Introduction

Job stress in the workplace appears to be a wide spread cross-cultural phenomenon. Most of the research work on stress has focused on basic elements, namely (a) antecedents of stress, (b) mediators of stress and (c) outcomes of stress (Jerusalem, 1993, as cited in Deary \& Blenkin, 1996). Depending on the subject's characteristic coping response, potential stressors may result in different outcomes in terms of physical and psychological disturbances (Endler \& Parker, 1990a, as cited in Deary \& Blenkin, 1996). Stress models typically show personality and environmental factors as having a strong influence on stress outcomes and coping methods (Cohen and Williamson, 1991; Maddi, 1990; Revicki \& May, 1985, as cited in Deary \& Blenkin, 1996). In the case of personality, the dimension of neuroticism, one of the five personality traits, is thought to be an influential antecedent in human stress process (Deary \& Matthews, 1993).

Not all job stress is deemed harmful. Stress affects people differently. Some people seem to thrive on extremely stressful lifestyles, while others struggle to cope with everyday life (Williams \& Cooper, 2002). Everyone has an optimum level of stress. Too little excitement and too few challenges may lead to an extremely dull life, yet too much stress can lead to health problems. Nevertheless, a certain amount of stress can actually prove to be good for individuals (Beehr \& Newman, 1978). Stress is also extremely useful in acting as an enabler to avoid problems and dangers. It is a motivator to solve problems and is an important warning signal that something is wrong with an individual's life, thereby allowing him or her to take some action (Williams \& Cooper, 2002).

In many countries, employers have a legal responsibility to recognize and deal with stress in the workplace so that employees do not become physically or mentally ill. It is important to tackle the causes of stress in the workplace as stress at work can lead to problems for the individual, working relationships and the overall working environment. 
These issues may include lowered self-esteem and poor concentration skills for the employee. The employer may suffer from increasing customer complaints, staff turnover and days lost to sickness. Managing stress in the workplace is therefore an essential part of both individual and corporate responsibility.

This case study in this research was conducted to gauge the job stress among managers in the electronics industry, thus, is not a representation of management job stress in generic or applicable to any other industries.

\section{Problem Statement}

Stress is a state that occurs when people are faced with events they perceive as endangering their physical or psychological well-being, and are unsure of their ability to deal with these events (Cook \& Hunsaker, 2001). Sources of stress are called stressors. Stressors, based on most studies include variables like environment, individual and organization (Matteson \& Ivancevich, 1999). For the past decade, the manufacturing sector has been undergoing constant technological development (Jestin \& Gampel, 2002). This inevitably leads to high pressure and job stress among managers in the work environment. Above all, the recent economic slowdown in the global economy has a significant effect on the local and multinational firms involving thousands of managers in the country. With the presence of job stress in the current world unavoidable, the big question is, whether the managers are aware of the best methods to cope and adapt to these challenges.

\subsection{Literature Review and Theoretical Framework}

\subsubsection{Job Stress among Managers}

Cooper (1984) reported that managers are experiencing physiological symptoms from job-related stress such as ulcers and coronary heart disease. These problems are forcing them to retire before they can reach their full managerial potential. Looking more at a specific area, Margetts (1969), as cited in Cooper (1984) addressed the stress problem related to business mergers and acquisitions. Many executives either are a part of this process or have the threat constantly present. The individual most affected is the highly paid, secure executive who has been with the company twenty years or more climbing the corporate ladder. Executives of large corporations are not the only individuals having high levels of stress in the business community. Executives of mid-size and small businesses are also experiencing job-related stress problems. Boyd \& Gumpert (1983), as cited in Kahler, (1987), conducted a study with 450 entrepreneurs whose companies ranged from fewer than ten to more than 500 employees. They concluded that because of keen competition and vast amounts of responsibility that accompany middle- and small-sized operations, high levels of stress are inevitable. Cooper and Payne, (1980), as cited in Kahler, (1987) also concluded that entrepreneurs live under a considerable degree of stress and are major stress inducers in their organizational environment. The study made a detailed explanation of the entrepreneurial personality and concluded that since entrepreneurs' self-induce stress, their adaptive behaviors are limited, thereby causing perpetuation of stressful events.

A survey conducted among American managers indicated that $41 \%$ of managers have more work than time (Fisher, 1985, as cited in Miller and Ellis, 1990). Hall \& Savery (1986) added the managers must respond to conflicting demands from governmental agencies, union representatives, and the community, in addition to their supervisors and subordinates. In recent years, managers have been subjected to stress resulting from economic recessions, organization downsizings and subsequently from the increased use of participatory management and computer systems which have led to many lay-offs (Murray \& Forbes, 1986). Such stress will not only be experienced by those losing their jobs but also for those remaining in the organization.

\subsection{Coping Methods and Job Stress}

The manner in which a person chooses to deal with stressful situations is called coping (Sethi and Schuler, 1984). Coping behaviors can be positive or negative, effective or ineffective. Effective and ineffective behaviors are a matter of individual personality and choice. What works for one individual may not work for another (Benson, 1976, as cited in Kahler, 1987). Positive and negative coping behaviors are also a matter of individual personality and choice and reinforced through research. Lazarus and Folkman, (1984) pioneers in the study of coping, defined this concept as "constantly changing cognitive and behavioral efforts to manage specific external and/or internal demands that are appraised as taxing or exceeding the resources of a person". These cognitive and behavioral efforts are directed at mastering, tolerating, reducing and/or minimizing environmental and internal demands and conflicts that strain an individual's resources (Schafer, 2000). During the coping phase, the individual acts on the stressor and the activities and efforts chosen are largely dependent on the variety of personal and environmental resources that are at the disposal of the individual (Schafer, 2000).

A further source of confusion derives from the fact that a strategy used by an individual in coping with a stressor can become a resource for that individual through prolonged successful use (Hammer and Marting, 2004). For example, one strategy for coping with stress is to make use of social supports. It is hypothesized that through continued successful use of such supports, benefits would accrue above and beyond the effects of using that strategy in a specific situation. Such benefits could take the form of an assurance that the supports are available and have been helpful in the past. These 
benefits would exert their effect whenever the individual encountered another stressor. Stated differently, for a strategy to function as a resource, a considerable amount of time, effort, practice, and probably success in employing the strategy is required. On the other hand, different strategies can be tried, tested, and then discarded in favor of others with relative ease (Hammer and Marting, 2004).

\subsection{Demographics Factors and Job Stress}

Demographic variables such as gender, age, salary range, and length of working years, educational status and marital status are very much related to job stress (Howard and Frink, 1996, as cited in Rashed, 2001). In addition, Cooper et al., (1994) concluded that individual variables like personality traits and demographic factors like gender, age, work experience and education level does influence job stress. Hendrix (1989), as cited in Roberts et al. (1997), described demographic factors as moderators to stress models, and significantly influences job stress. Key demographic factors being investigated in Hendrix (1989), as cited in Roberts et al. (1997) study were age, gender, education level, marital status, position in company, job tenure and work experience.

\subsection{Theoretical Framework and Hypotheses}

The conceptual framework for this study, as shown in Figure 1 is based on Lazarus \& Folkman (1984) theory of stress and coping, and evidence from the job-stress literature. Coping methods moderate the relationship between independent variables and job stress. The demographic factors were included as control variables. The aim of this study is to determine the relationship between coping methods (Cognitive, Social, Emotional, Spiritual/ Philosophical, and Physical) (Hammers \& Marting, 1988) and job stress. Given the fact the demographic factors do influence job stress, individual variables such as gender, age, salary range, length of working years, educational status, marital status and job satisfaction. The coping methods will be the moderating variable to the dependent variable, namely, job stress, with demographics factors being the independent variable.

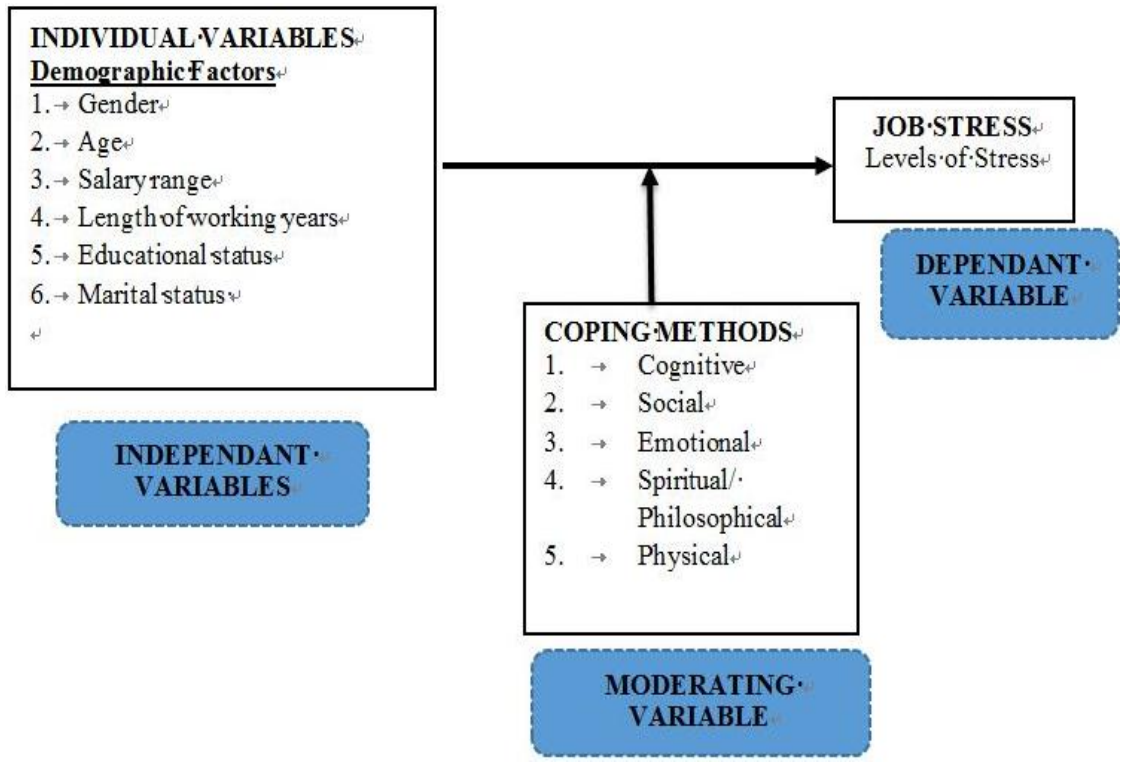

Figure 1. Theoretical Framework for this Research

The hypotheses for the present study will be relating coping methods (Cognitive, Social, Emotional, Spiritual/ Philosophical, and Physical) to job stress. Hammers \& Marting (1988; 2004) have tested and proved the acceptance of these coping methods and Lazarus (2006) on its influence to job stress. The hypotheses developed for the study are as shown below.

H1: Coping Methods as a moderator, influences job stress.

H1.1: Cognitive coping methods has a positive relationship with job stress

H1.2: Social coping methods has a positive relationship with job stress

H1.3: Emotional coping methods has a positive relationship with job stress

H1.4: Spiritual/ Philosophical coping methods has a positive relationship with job stress

H1.5: Physical coping methods has a positive relationship with job stress

\subsection{Definition of Key Variables}

Job stress is a key variable in this study and will be defined as follows: 
Job stress in this study is defined as a result of interaction between the individual with the job and environment that causes deviation in their normal functioning like being in anxiety, worried and depressed (Matteson \& Ivancevich, 1999; Beehr \& Newman, 1978).

The coping variables in this study includes resources from the Coping Inventory, namely, Cognitive, Social, Emotional, Spiritual/ Philosophical, and Physical, which is described as follows:

Cognitive is defined as the coping method to the extent to which individuals maintain a positive sense of self-worth, a positive outlook towards others, and optimism about life in general. The role of a positive self-concept in adaption to stress is well documented (Pearlin \& Schooler, 1978 as cited in Hammer and Marting, 2004).

Social is defined as to the degree to which individuals are imbedded in social networks that are able to provide support in times of stress (Hammer \& Marting, 2004).

Emotional is defined as to the degree to which the individuals are able to accept and express a range of affect, based on the premise that a range of emotional response aids in ameliorating long term negative consequences of stress (Hammer \& Marting, 2004).

Spiritual/Philosophical refers to the degree to which actions of individuals are guided by stable and consistent values derived from religious, familial or cultural tradition or from personal philosophy. Such values might serve to define the meaning of potentially stressful events and to prescribe strategies for responding effectively. The content domain for this scale is broader than traditional western religious definitions of spirituality (Hammer \& Marting, 2004).

Physical is defined as the degree to which individuals enact health-promoting behaviors believed to contribute to increase physical well-being. Physical well-being is thought to decrease the level of negative response to stress and to enable faster recovery. It may also help to attenuate potentially chronic stress-illness cycles resulting from negative physical responses to stressors that they become major stressors (Hammer \& Marting, 2004).

\section{Methods}

This research is encompassed by a study using 400 managers from random electronics firms in Malaysia. The questionnaires were given in a hard-copy format and a time study was conducted. This is a field study and no artificial setting was created as it examines manager's coping styles towards job stress in their natural work environment. Each individual manager represents the unit of analysis in this study. In this research, electronics firms/factories were randomly selected based on a proportion sampling plan, based on the weighted percentage of the distributions of these electronics firms by states. This selection provided homogeneity in terms of electronics industry, yet it offered diversities in organization culture, which were dependent on the firm's country of origin. The first level sampling involves proportional study on the electronics firms' population in Malaysia. This data is obtained from the Malaysian Industrial Development Authority (MIDA), Latest Update 2009. The second level sampling involves identifying the number of firms located in these key industrial areas in Malaysia, proportion to the density of the electronics firms. The third level sampling involves the population of managers from the randomly selected firms.

\subsection{Variables and Measurement}

All instruments were previously used from published literature (Davis, et al., 2000; Hammer \& Marting, 1988). The survey measurement scale except the demographic profile utilizes a 5-point Likert response format for job stress measure, while the coping inventory utilizes a 4-point Likert response format. Job Stress Variable - job stress variable will perform a function of dependent variable to the antecedent variable (organizational sources of stress and personality variables). Job stress will be measured using a screening inventory which helps indicate one's levels of job stress (Davis et al., 2000). Coping Variables - Dimensions of coping will be accessed using the Coping Resources Inventory (CRI) (Hammers \& Marting, 1988). This inventory will tabulate coping methods, namely Cognitive, Social, Emotional, Spiritual/ Philosophical, and Physical. Coping resource inventory covers 5 domains of resources. Cognitive scale addresses an individual's optimism about life and sense of self-worth. Social scale measures how much the person feels a part of social network that one can count on during the times of stress. Emotional scale refers to an individual's ability to accept and express emotions. Spiritual or philosophical scale accesses extent to which an individual is influenced by values from religion, traditions or personal philosophy. Physical scale covers an individual's health-promoting behaviors.

\subsection{Methods of Analysis}

Job stress can be directly influenced by personal factors (Matteson \& Ivancevich, 1999). Six individual variables, from 
the demographic factors, namely gender, marital status, educational background, length of working years, age and salary range, were all statistically controlled as the independent variable for this study, following previous researches (Cooper et al., 1994; Roberts et al., 1997; Rashed, 2001). To test all the hypotheses of the study, hierarchical regression will be done to determine the relationship between the job stress and the coping variables, statistically controlling the demographic variables. Examination on multicollinearity and its effects will also be done to further validate the regression results. The two part process (condition indices and the decomposition of the coefficient variance) will be done and comparisons will be made with the conclusions drawn from the variance inflation factor (VIF) and tolerance values. The condition indices and VIF not exceeding threshold value of 10 will be used (Hair, 1988 as cited in Ndubisi et. al., 2001). A threshold of 3 standard deviation will be used to identify outliers. The model summary and ANOVA tests was also performed to check the $\mathrm{R}^{2}$ and $\mathrm{F}$ values to test whether the variables used in this study was sufficient and valid, plus utilization of these variables to measure job stress fits in the multivariate model.

\section{Results and Analysis}

\subsection{Validity of the Instruments}

In the present study, data collected from different segments of the electronic industry in order to find out the influence of coping methods and individual factors on job stress. Content validity of the instrument was carried out through a Delphi technique by interviewing the first line managers, regional managers and some senior managers working in both domestic and multinational electronic companies at Malaysia. A total of 400 valid surveys was collected and analyzed, out of a total of 700 surveys sent. A socio demographic profiling was done from all the respondents that would analyze the breakdown by gender, age, salary range, length of working experience and educational status, marital status, as shown in Table 1.

Table 1. Overall Summary of Demographic profile of the respondents by frequency and Percentage

\begin{tabular}{|c|c|c|c|}
\hline Factors & Variables & Frequency & Percent \\
\hline \multirow{3}{*}{ Gender } & Male & 179 & 44.8 \\
\hline & Female & 221 & 55.2 \\
\hline & Total & 400 & 100.0 \\
\hline \multirow{6}{*}{ Age } & Less than 30 years & 3 & 0.8 \\
\hline & 30-35 years & 123 & 30.8 \\
\hline & $35-40$ years & 154 & 38.5 \\
\hline & $40-45$ years & 102 & 25.5 \\
\hline & Above 45 years & 18 & 4.5 \\
\hline & Total & 400 & 100.0 \\
\hline \multirow{6}{*}{ Salary Range } & Below RM 5000 & 68 & 17.0 \\
\hline & RM 5000 - RM 10000 & 170 & 42.5 \\
\hline & RM 10000 - RM 15000 & 97 & 24.3 \\
\hline & RM 15000 - RM 20000 & 65 & 16.3 \\
\hline & Above 20000 & 0 & 0.0 \\
\hline & Total & 400 & 100.0 \\
\hline \multirow{6}{*}{ Working Experience } & Less than 1 year & 0 & 0.0 \\
\hline & 1 year -5 years & 25 & 6.3 \\
\hline & 5 years -10 years & 227 & 56.8 \\
\hline & 10 years -15 years & 115 & 28.8 \\
\hline & More than 15 years & 33 & 8.3 \\
\hline & Total & 400 & 100.0 \\
\hline \multirow{5}{*}{ Educational Background } & $\begin{array}{c}\text { Diploma/Advanced } \\
\text { Diploma }\end{array}$ & 4 & 1.0 \\
\hline & Bachelor's Degree & 251 & 62.8 \\
\hline & Master's Degree & 143 & 35.8 \\
\hline & $\mathrm{PhD} /$ Doctorate & 2 & 0.5 \\
\hline & Total & 400 & 100.0 \\
\hline \multirow{4}{*}{ Marital Status } & Single & 119 & 29.8 \\
\hline & Married & 261 & 65.2 \\
\hline & Separated/Divorced & 20 & 5.0 \\
\hline & Total & 400 & 100.0 \\
\hline
\end{tabular}

Among the 400 respondents, $44.8 \%$ of them were male and $55.2 \%$ were female. In terms of marital status, $65.2 \%$ of them were married managers, while $29.8 \%$ single. Educational status showed heavier number of managers currently with a bachelor's degree at $62.8 \%$, while $35.8 \%$ of them were master's degree holders. Small population with either diploma/advanced diploma or PhD. at 1.5\%. Majority of the managers surveyed had a working experience of 5-10 years at $56.8 \%$, followed by $10-15$ years at $28.8 \%$. Salary range showed most managers earning between RM5000-RM10000 at $42.5 \%$, while $24 \%$ of them earned between RM10000-RM15000. Biggest age group was between 35-40 years old, at 
$38.5 \%$, followed by $30-35$ years old at $30.8 \%$ and $40-45$ years old at $25.5 \%$. Through simple random and weighted sampling, data was collected from the managers from the electronics industries, from major industrial states in Malaysia. Descriptive statistics for mean and standard deviation is shown in Table 2.

Table 2. Descriptive Statistics for Coping and Job Stress Variables

\begin{tabular}{lccc}
\hline & Descriptive Statistics & Std. Deviation & $\mathrm{N}$ \\
\hline Job stress & Mean & 11.646 & 400 \\
Cognitive & 52.703 & 4.343 & 400 \\
Social & 25.550 & 4.930 & 400 \\
Emotional & 37.548 & 4.572 & 400 \\
Spiritual/Philosophical & 49.035 & 3.851 & 400 \\
Physical & 33.743 & 3.670 & 400 \\
\hline
\end{tabular}

Reliability and validity of the instruments were carried out for all the independent, mediating and dependent variables. Cronbach's Alpha value for all variables (coping variables and job stress) all scored between 0.6-0.9, indicating the instrument had strong to acceptable internal consistency of reliability (Sekaran, 2000; Page, 2000). Construct validity test was also done to determine the validity of every questions in the instrument used. Out of the six variables tested, three of them, namely job stress, cognitive and social, all had zero questions at below 0.4 Cronbach's Alpha value, if any of the related questions were deleted, showing very good inter-correlation among those questions, within the specific variable. Spiritual/philosophical had three question scoring below 0.4 , followed by two for physical, respectively, for questions below 0.4 Cronbach's Alpha value, if questions/items were deleted. All this is summarized in Table 3 as shown below.

Table 3. Reliability tests (Cronbach's Alpha value) for All Variables

\begin{tabular}{rlrr}
\hline Sl. no & Variables & Cronbach's Alpha value & No. of items \\
\hline 1 & Job stress & 0.918 & 20 \\
2 & Cognitive & 0.698 & 9 \\
3 & Social & 0.682 & 13 \\
4 & Emotional & 0.705 & 16 \\
5 & Spiritual/Philosophical & 0.617 & 11 \\
6 & Physical & 0.645 & 11 \\
\hline
\end{tabular}

Model summary and coefficient of ANOVA testing for coping methods to job stress $\left(\mathrm{R}^{2}=92.0 \% ; \mathrm{F}=906.909\right)$, indicating the variables used in this study was sufficient and valid, plus utilization of these variables to measure job stress fits in the multivariate model. Besides the theoretical framework being supported by previous researches (Karasek, 1979; Lazarus and Folkman, 1984), the qualitative study adopted during the pilot study that covered presentations, interviews and personal dialogues with sampled managers, had a huge impact to the healthy $R^{2}$ and $F$ numbers given by the model summary and ANOVA tests, as shown in Table 4 below.

Table 4. Model Summary and Coefficient of determination of ANOVA for Coping Variable

\begin{tabular}{|c|c|c|c|c|}
\hline \multicolumn{5}{|c|}{ Model Summary } \\
\hline Model & $\mathrm{R}$ & R Square & Adjusted R Square & $\begin{array}{l}\text { Std. Error of the } \\
\text { Estimate }\end{array}$ \\
\hline dimension 1 & $.959^{\mathrm{a}}$ & .920 & .919 & 3.31349 \\
\hline \multicolumn{5}{|c|}{ a. Predictors: (Constant), Physical, Cognitive, Spiritual/Philosophical, Emotional, Social } \\
\hline
\end{tabular}

\begin{tabular}{llrrrrr}
\hline \multicolumn{7}{c}{ ANOVA $^{\mathbf{b}}$} \\
\hline Model & & Sum of Squares & df & Mean Square & F & Sig. \\
\hline \multirow{2}{*}{1} & Regression & 49785.783 & 5 & 9957.157 & 906.909 & $.000^{\mathbf{a}}$ \\
& Residual & 4325.815 & 394 & 10.979 & & \\
& Total & 54111.598 & 399 & & & \\
\hline
\end{tabular}

a. Predictors: (Constant), Physical, Cognitive, Spiritual/Philosophical, Emotional, Social

b. Dependent Variable: Job stress

During the pilot study on 40 respondents, 25 of them was subjected to a qualitative study and was interviewed in relation to their job satisfaction, job stress awareness and actions taken by their employers or individuals on managing those stressful situations. Almost all of them, in summary, was satisfied with their managerial job, and was aware of the types of stressors that would cause job stress. Everyone agreed that among all stressors, conflict, overload and work conditions would cause any employees in any positions to not be at their best in their job and career. Interesting finding, 
was most of them were not aware of any coping methods that can be associated with the stressors and personality traits of a certain individual. Majority of them agreed that in spite of some employers would focus on promoting Work Life Effectiveness or Balanced Work; there was no programs or efforts to manage individual employees suffering from any specific kind of job stress.

\subsection{Regression Analysis on Coping Methods}

Regression weights of all coping methods against the constant variable, job stress. The results are as shown in Table 5 below.

Table 5. Pearson Correlation Analysis among Coping Methods and Job Stress

\begin{tabular}{ccccccc}
\hline & Cognitive & Social & Emotional & $\begin{array}{c}\text { Spiritual/ } \\
\text { Philosophical }\end{array}$ & Physical & Job stress \\
\hline Cognitive & 1.000 & 0.657 & 0.542 & 0.473 & 0.210 & 0.937 \\
Social & 0.657 & 1.000 & 0.481 & 0.587 & 0.515 & 0.730 \\
Emotional & 0.542 & 0.481 & 1.000 & 0.519 & 0.577 & 0.617 \\
$\begin{array}{c}\text { Spiritual/ } \\
\text { Philosophical }\end{array}$ & 0.473 & 0.587 & 0.519 & 1.000 & 0.224 & 0.509 \\
Physical & 0.210 & 0.515 & 0.577 & 0.224 & 1.000 & 0.382 \\
Job stress & 0.937 & 0.730 & 0.617 & 0.509 & 0.382 & 1.000 \\
\hline
\end{tabular}

In this study, out of five variables tested, against job stress among managers in the electronic industry, all the variables such as cognitive, social, emotional, and physical coping methods are significant at five percent level. This means an increase in job stress would increase cognitive, social, emotional, and physical coping methods adopted by the managers. Spiritual/Philosophical coping method were not significant $(p=0.492)$ The larger the $B$ value for unstandardized coefficients, the bigger the impact of the variable is, in terms of the magnitude of its influence to job stress. This in study, cognitive had a B value of 2.185 ( $\mathrm{p}=0.000)$, that indicates a strong significance at $95 \%$ level, and positively increases for an increase in job stress. Studies have supported this finding, which indicates that the adoption of the coping methods like cognitive (Pearlin and Schooler, 1978), social (Davidson et al., 1995, as cited in Lloyd, 2014) and emotional (Carver and Scheier, 1985, as cited in Folkman and Lazarus, 1980) coping strategy for job stress is much more favored.

\subsection{Hypotheses Testing}

Spearman correlation test has been carried out to test the framed hypothesis in the study. Among many correlation methods, the spearman correlation method has been used because both the dependent variable (job stress) and the coping methods are both in continuous (Likert's) scale (Jerome and Arnold, 2003). Table 6 shows the Spearman correlation analysis for the five tested hypotheses.

Table 6. Regression Weights of All Coping Methods and Job Stress

\begin{tabular}{|c|c|c|c|c|c|c|c|c|}
\hline \multirow{3}{*}{\multicolumn{2}{|c|}{ Model }} & \multicolumn{4}{|c|}{ Coefficients $^{\mathrm{a}}$} & \multirow{3}{*}{ Sig. } & \multirow{2}{*}{\multicolumn{2}{|c|}{$\begin{array}{l}\text { Collinearity } \\
\text { Statistics }\end{array}$}} \\
\hline & & \multicolumn{2}{|c|}{$\begin{array}{l}\text { Unstandardized } \\
\text { Coefficients }\end{array}$} & \multirow{2}{*}{$\begin{array}{c}\text { Standardized } \\
\text { Coefficients } \\
\text { Beta }\end{array}$} & \multirow[t]{2}{*}{$\mathrm{t}$} & & & \\
\hline & & B & $\begin{array}{l}\text { Std. } \\
\text { Error }\end{array}$ & & & & Tolerance & VIF \\
\hline 1 & (Constant) & 32.710 & 2.004 & & 16.324 & .000 & & \\
\hline & Cognitive & 2.185 & .059 & .815 & 36.753 & .000 & .413 & 2.422 \\
\hline & Social & 1.230 & .059 & .097 & 3.860 & .000 & .320 & 3.126 \\
\hline & Emotional & 1.116 & .058 & .046 & 2.001 & .001 & .389 & 2.570 \\
\hline & Spiritual/Philosophical & .041 & .060 & .014 & 1.687 & .492 & .522 & 1.915 \\
\hline & Physical & .417 & .068 & .131 & 6.140 & .000 & .443 & 2.256 \\
\hline & ependent Variable: Job s & & & & & & & \\
\hline
\end{tabular}

$$
\mathrm{Y}=32.710+2.185 \mathrm{X}_{1}+1.230 \mathrm{X}_{2}+1.116 \mathrm{X}_{3}+0.041 \mathrm{X}_{4}+0.417 \mathrm{X}_{5}+\mathrm{C}
$$

H1.1 testing showed that cognitive have a strong correlation on job stress at $92.6 \%(\mathrm{p}=0.000)$, hence based on this, the alternate hypothesis is accepted and it is confirmed the cognitive coping method will positively influence job stress. Cognitive coping methods have been widely researched. Cognitive method is a positive self-concept in adaption to stress (Pearlin \& Schooler, 1978, as cited in Hammer \& Marting, 2004). The cognitive stress-coping resource (problem-focused or task-oriented) is indicative of one's ability to maintain a positive outlook toward others, sense of self-worth, and optimism about life in general (Lazarus, 2006). Cognitive stress-coping resource is employed more often when an individual feels that something constructive can be done (Carver \& Scheier, 1985, as cited in Folkman \& Lazarus, 1980). 
Table 7. Spearman's Correlation for Coping Methods and Job Stress (Hypotheses Testing)

\begin{tabular}{|c|c|c|c|c|c|c|c|}
\hline \multicolumn{8}{|l|}{ Correlations } \\
\hline Spearman's rho & & Job stress & $\begin{array}{l}\text { Cognitiv } \\
\text { e }\end{array}$ & Social & $\begin{array}{l}\text { Emotion } \\
\text { al }\end{array}$ & $\begin{array}{l}\text { Spiritual/Philos } \\
\text { ophical }\end{array}$ & $\begin{array}{l}\text { Physic } \\
\text { al }\end{array}$ \\
\hline \multirow[t]{2}{*}{ Job stress } & $\begin{array}{l}\text { Correlation } \\
\text { Coefficient }\end{array}$ & 1.000 & 0.926 & 0.756 & 0.664 & 0.155 & 0.144 \\
\hline & Sig. (2-tailed) & . & 0.000 & 0.000 & 0.000 & 0.113 & 0.247 \\
\hline \multirow[t]{2}{*}{ Cognitive } & $\begin{array}{l}\text { Correlation } \\
\text { Coefficient }\end{array}$ & 0.926 & 1.000 & 0.676 & 0.489 & 0.397 & 0.177 \\
\hline & Sig. (2-tailed) & 0.000 & . & 0.000 & 0.000 & 0.000 & 0.000 \\
\hline \multirow[t]{2}{*}{ Social } & $\begin{array}{l}\text { Correlation } \\
\text { Coefficient }\end{array}$ & 0.756 & 0.676 & 1.000 & 0.362 & 0.488 & 0.410 \\
\hline & Sig. (2-tailed) & 0.000 & 0.000 & . & 0.000 & 0.000 & 0.000 \\
\hline \multirow[t]{2}{*}{ Emotional } & $\begin{array}{l}\text { Correlation } \\
\text { Coefficient }\end{array}$ & 0.664 & 0.489 & 0.362 & 1.000 & 0.439 & 0.536 \\
\hline & Sig. (2-tailed) & 0.000 & 0.000 & 0.000 & . & 0.000 & 0.000 \\
\hline \multirow[t]{2}{*}{$\begin{array}{l}\text { Spiritual/Philo } \\
\text { sophical }\end{array}$} & $\begin{array}{l}\text { Correlation } \\
\text { Coefficient }\end{array}$ & 0.155 & 0.397 & 0.488 & 0.439 & 1.000 & 0.141 \\
\hline & Sig. (2-tailed) & 0.113 & 0.000 & 0.000 & 0.000 & . & 0.005 \\
\hline \multirow[t]{2}{*}{ Physical } & $\begin{array}{l}\text { Correlation } \\
\text { Coefficient }\end{array}$ & 0.144 & 0.177 & 0.410 & 0.536 & 0.141 & 1.000 \\
\hline & Sig. (2-tailed) & 0.247 & 0.000 & 0.000 & 0.000 & 0.005 & . \\
\hline
\end{tabular}

H1.2 testing showed that social have a good correlation on job stress at $75.6 \%(\mathrm{p}=0.000)$, hence based on this, the alternate hypothesis is accepted and it is confirmed the social coping method will positively influence job stress. Some studies have supported this finding. The social stress-coping resource is indicative of the availability of social networks that can provide support in times of stress. Seeking assistance from others and gaining social support from personal social networks are useful methods for decreasing levels of stress (Davidson et al., 1995, as cited in Lloyd, 2014). Researcher (Mutran et al., 1997) indicate that marital quality is positively related to stress, because persons living with spouses are better adjusted socially.

H1.3 testing showed that emotional have a correlation on job stress at $66.4 \%(\mathrm{p}=0.000)$, hence based on this, the alternate hypothesis is accepted and it is confirmed the emotional coping method will positively influence job stress, anyhow, this correlation was weaker compared to cognitive and social methods. Emotional stress-coping resource engagement is engaged when an individual feels that a stressor must be tolerated (Carver \& Scheier, 1985, as cited in Folkman \& Lazarus, 1980). Emotion-focused stress-coping resource has been also found to be positively related to distress and worry (Matthews et al., 2000, as cited in Lloyd, 2014).

H1.4 test showed spiritual/philosophical have a no correlation and significance on job stress at $15.5 \%(\mathrm{p}=0.113)$, hence based on this, the alternate hypothesis is rejected and it is confirmed the spiritual/philosophical will not influence job stress. There are supporting literatures for this finding. Spiritual/philosophical stress-coping resource plays an important role in moderating the negative effects of perceived stress (Kim \& Seidlitz, 2002, as cited in Lloyd, 2014), thus enables an individual to manage job stress better. Individuals with a stronger sense of spirituality are able to maintain a more positive sense of overall satisfaction with life and work when faced with internal or external negative encounters (Fabricatore, et al., 2000, as cited in Lloyd, 2014).

H1.5 test showed physical have a no correlation and significance on job stress at $14.4 \%(\mathrm{p}=0.247)$, hence based on this, the alternate hypothesis is rejected and it is confirmed the physical will not influence job stress. This finding does not support the previous studies that have found that the physical stress-coping resource is rooted in the stress-buffering effect of the existing stressful situation (Calvete \& Connor- Smith, 2006, as cited in Lloyd, 2014). Anyhow, physical stress-coping resource enhances the coping efforts by providing additional mental pausing to process available information related to internal or external stressors (Holahan, et al., 1997, as cited in Lazarus \& Folkman, 1984), which would enable an individual who copes stress through physical activities would experience lower levels of job stress.

\section{Discussions}

\subsection{Major Findings}

Hypotheses was tested based on the influence of coping variables, as a mediator to job stress. Regression results showed very strong positive relationship between cognitive coping methods to job stress, with strong significance at $95 \%$ level $(\mathrm{p}=0.000)$. This was further supported by $92.6 \%$ correlation between cognitive and job stress, via Spearman test. Both social and emotional coping methods also showed significant relationship positively to job stress, and further supported by the correlation strength at $75.6 \%$ (social) and $66.4 \%$ (emotional). Subsequently for the other two methods, 
spiritual/philosophical and physical, no correlations were found with job stress. Spiritual/philosophical method showed no significance to job stress using the regression analysis. Cognitive in general stood out in this study, as a strong coping method being adopted by managers in the electronics industries in Malaysia. Social and emotional methods were also showing good correlations.

Cognitive means relating to or involving conscious mental activities such as thinking, understanding and learning. Cognitive coping is defined as the coping method to the extent to which individuals maintain a positive sense of self-worth, a positive outlook towards others, and optimism about life in general. Cognitive coping provides positive adaptation outcomes. Proactive thinking and proper planning when potentially stressful activities are anticipated are key attributes of cognitive coping methods, as expressed by previous researchers (Aspinwall, 2005, as cited in Lloyd, 2014; Lazarus \& Folkman, 1984). The finding in this study shows strong correlation of managers in the electronics industry to have high tendency to ensure their outlook and self-worth are reflected positively. In common, most managers with strong cognitive approach and methods as a coping style, feel that they are worthwhile as anyone else. These group of manager also show case high self-esteem and how people perceive them is somewhat critical in how the managers view their advancements in their career. It is found that most managers that are actively using this coping method are individuals that spend more time to analyze, understand and think in detail about any situations or scenarios. This relates to the demand that the electronics industry has on their management team, in terms of growing the business and creating new investment opportunities for the future. Strong cognitive method usage as a coping style has vast coverage in previous researches. The use of cognitive methods in a role of a positive self-concept in adaption to job stress is well documented (Pearlin \& Schooler, 1978, as cited in Hammer \& Marting, 2004). Cognitive stress-coping was found helpful in building individual's self-efficacy over time because this involves attempts by the user to change or eliminate the stressor (Folkman \& Lazarus, 1980). Another supporting study on managers with cognitive style suggested this method is preferably adopted more often when the manager feels that something constructive can be done and that a stressor must be tolerated (Carver \& Scheier, 1985, as cited in Folkman \& Lazarus, 1980).

Social and emotional coping methods were also found to be used by managers, but at a lesser intensity compared to cognitive method. Social methods would involve the sense of being with others around you, like family and friends. Social support consists of the tangible and intangible rewards and assistance provided by the significant others. Emotional on the other hand is defined as a measures the degree to which individuals are able to accept and express a range of affect. Social method as a coping strategy is pretty common in organizations like the ones tested in electronics industry in Malaysia. One of the most significant reasons was many electronics firms promote team building, collaborations and networking events, to build a strong performing team. This culture that vastly promotes getting out to meet and talk to people, during work and off work hours, will result in a more sociable society, in which many managers would use as a coping method, to vent out their job related stresses. Emotional on the other hand is very different from the social method. When managers roam into emotional world, most of them would tend to be left alone or would be looking for some personal time to be away from people, and internally try to absorb and administer the problems they face. From the social coping perspective, Mutran et al. (1996) researched on this topic and found professionals that have a life partner or strong support from family and friends, are better adjusted socially and emotionally, experience less loneliness, have a higher morale, and enjoy better health than those who are unmarried or do not have another person to fall back to. The degree to which individuals are imbedded in social networks that are able to provide support in times of stress (Hammer and Marting, 2004). From the emotional coping perspective, previous studies have supported the usage of this method among the management professionals. Cameron (2005) found that the most satisfying and beneficial motivation is when it is generated from within. The study also found emotional methods of coping is practiced by individuals that have positive emotions that can help in aligning focus and boosting energy to maximize performance.

Spiritual/philosophical and physical coping methods did not result in any significant relationship to job stress, in this study. Wiggins (1994) supported this in his research, that found religion and spiritual approaches becomes important for an individual only at a later stage of one's life and might not be practiced widely during their working days. Another study found that physical coping methods were perceived critical in maintaining individual well-being and a promoter for good health, rather than a coping method for job stress (Parker et al., 2004; Wang et al., 2009, as cited in Lloyd, 2014).

\subsection{Implication and Contributions}

A couple of viewpoints are discussed here. Theoretical viewpoint of this study reveals that coping methods does moderate job stress, with cognitive method being the most preferred coping style among managers, while social and emotional methods were still found to be highly used among managers. Individual/managerial viewpoint is constructed based on how the importance of these findings and how it reflects individually to the manager. Beyond all, the right coping methods is critical. Like what was found in this study, cognitive method is the most popular way for managers to 
cope with their job stress, so individuals should understand more on what is cognitive method and what avenues would enable them to practice being cognitively competent in enabling managers to directly or indirectly vent their stressful situations at work. This would allow managers to understand their coping methods to job stress, thus ensuring their social, professional and family lives are well balanced. From the organizational viewpoint, the whole model of understanding what causes job stress and how the job stress can be coped effectively to result in highly productive managerial staffs will be very beneficial, for any organizations. In understanding, acknowledging and managing the coping methods to job stress would enable companies to promote more cognitive related activities like social events, team buildings, conferences, community of practices for common hobbies that would allow and enable managers to be in the environment that would best suit and promote their ability to manage with job stress effectively. Economic viewpoint is more from the benefits to the nation and the economy of the country, through the establishment of a better stress management process and system within the electronics firms. With the helm of every company's leadership for electronics sector being more composed, balanced work life and highly productive, it shapes well for growth in Malaysia for electronics industry in general. With the rightful coping methods used to overturn job stresses negative influence to be more positively used, these vision to drive and boost the Malaysian economy in terms of the electronics sector would take a positive turn upward.

Contributions in of this study would be timely, for the electronics industry being one of the nation's big economic drivers, is experiencing down-sizing and slow down, due to global economic situations. The findings on coping methods for managers with specific personality and demographics will enable a better job stress management, which will be phenomenal for the productivity and the well-being of the individual manager and the continued success of the electronics firms. This will allow firms and companies to develop avenues to suit the rightful facilities and forums to address job stress for their employees. This would result in a more balanced managerial workforce in terms of work life effectiveness, which will result in highly motivated individuals, a happier society, highly productive organizations and a huge economy boost for the nation.

\subsection{Limitation of the Study}

From the methodology perspective, the sample size that was used in this study was 400, from various electronics firms around Malaysia. Key contributing states would include Pulau Pinang, Kuala Lumpur, Selangor and Johor. In view of that, a larger sample would provide a statistically firmer base to access the relationship between the independent variables and coping methods to job stress among managers in Malaysia. A larger sample size is preferred, to generalize the findings. There are also many other instruments to measure coping methods for an individual. Similarly, this study used coping methods as a moderator, while there may be many other variables that can be a moderator for job stress that was not studied here. Another key note is the study only targets the electronics industry in Malaysia, hence the results obtained from this study may not be applicable to other industries like textile, transportation, steel, chemicals, and government sectors and so forth.

From the managers' perspective as the key sample for this study, the key limitation related to job stress itself. In this context, job stress is defined as stress faced by managers at work place, where as in the actual fact, managers would experience stresses from other sources besides job, which would have a direct implication to their respective stress levels at work. These external factors were not investigated in this study. Physiological state of mind of the managers when they are answering the survey would play a big part in the outcome of the study. Finally from the environmental perspective, the country's economic conditions and stability plays a significant role in determining the manager's job stress in the electronics industry, especially when electronics are Malaysia's biggest contributor in terms of export based income. This external factor was not considered during the time of the study, and will have a significant impact to the levels of job stress among the managerial workforce. The other significant environmental difference that was not include in this study was the country of origin of the electronics firm. It is believed that the stress levels at work experienced by employees are different for different origins of the company, due to its internal culture.

\section{Conclusion}

In summary, the study provided insight on the validity of the stress model using managers' sample in the electronics industry the Malaysia. The findings in this study suggest that the stress models developed by previous scholars like Lazarus and Folkman (1984) and Matteson and Ivancevich (1999), can be applied within the Malaysian context. This study as a whole concludes that job stress is widely presence among managers in the electronics industry in Malaysia. Cognitive coping method was very prevalent among managers to job stress for both genders. Social and emotional coping methods were also optional methods used by managers to cope with job stress. It is with hope that the finding of this study will be useful for managers individually and organizations to understand the presence of job stress and possible methods that would enable managers to cope with job stress effectively. 


\section{References}

Beehr, T. A., \& Newman, J. E. (1978). Job Stress, Employee Health and Organizational Effectiveness: A Facet Analysis, Model and Literature Review. Personnel Psychology, 31, 665-699. http://dx.doi.org/10.1111/j.1744-6570.1978.tb02118.x

Cameron, D. (2005). From work to retirement: How to create a fulfilling life. Australia: Indian Ocean Books.

Cohen, J. (1988). Statistical power analysis for the behavioral sciences. (2nd Ed.)

Cook, C. W., \& Hunsaker, P. L. (2001); Management and Organizational Behavior, ${ }^{\text {rd }}$ Edition, New York: McGraw Hill.

Cooper, C. L. (1984). Executive stress: A ten country comparison. Human Resource Management, $23(4), 395-407$. http://dx.doi.org/10.1002/hrm.3930230406

Cooper, C. L., Kirkaldy, B. D., \& Brown, J. (1994). A model of job stress and physical health: The role of individual differences. Personality and Individual Differences, 16, 653-655. http://dx.doi.org/10.1016/0191-8869(94)90194-5

Davis, M., Elizabeth, R. E., \& Matthew, M. (2000). The Relaxation and Stress Reduction Workbook. $5^{\text {th }}$ Edition. New Harbinger Publication, Inc., New York.

Deary, I. J., \& Blenkin, H. (1996). Models of job-related stress and personal achievement among consultant doctors. British Journal of Psychology; London, 87(1), 3-27. http://dx.doi.org/10.1111/j.2044-8295.1996.tb02574.x

Deary, I. J., \& Matthews, G. (1993). Personality traits are alive and well. The Psychologist, 6(12), $299-311$.

Folkman, S., \& Lazarus, R. S. (1980). An analysis of coping in a middle-aged community sample. Journal of Health and Social Behavior, 21, 219-239. http://dx.doi.org/10.2307/2136617

Hall, K., \& Savery, L. K. (1986). Tight rein, more stress. Harvard Business Review, 23(10), 1162-1164.

Hammer, A. L., \& Marting, M. S. (1988). Manual for the Coping Resources Inventory. California: Consulting Psychologists Press.

Hammer, A. L., \& Marting, M. S. (2004). Coping Resources Inventory, Revised. California: Consulting Psychologists Press.

Jerome, M. L., \& Arnold, W. D. (2003). Research Design and Statistical Analysis (2nd Ed.). Lawrence Erlbaum, 508.

Jestin, W., \& Gampel. A. (2002). The Big Valley, Global Outlook; Toronto: McGraw Hill.

Kahler, H. S. Jr. (1987). Stress management among corporate manager: A study of the relationship among management styles, management levels and coping behavior. Dissertation. Iowa State University, Ames, IA.

Lazarus, R. S. (2006). Emotions and interpersonal relationships: Toward a person centered conceptualization of emotions and coping. Journal of Personality, 74(1), 9-46. http://dx.doi.org/10.1111/j.1467-6494.2005.00368.x

Lazarus, R. S., \& Folkman, S. (1984). Coping and adaptation. In W. D. Gentry (Ed.). The handbook of behavioral medicine. New York: Guilford.

Lazarus, R. S., \& Folkman, S. (1984). Stress, Appraisal and Coping. New York, NY: Springer.

Lloyd, I. I. (2014) Emotional Intelligence and Stress-coping in High Stress Occupations. Dissertation. North Central University, 2014.

Malaysian Investment Development Authority (MIDA) 2013. Industries in Malaysia: Electrical and electronics industry, MIDA 2013

Matteson, M. T., \& Ivancevich, J. M. (1999); Organizational Behavior and Management, $5^{\text {th }}$ Edition, New York: McGraw Hill.

Miller, K., \& Ellis, B. H. (1990). An Integrated Model of Communication, Stress and Burnout in Workplace. Communication Research, 17(3), 27-300. http://dx.doi.org/10.1177/009365090017003002

Murray, T. J., \& Forbes, D. (1986). Where have all the middle managers gone? Dun's Business Month, 31-34.

Mutran, E., Reitzes, D. C., \& Fernandez, M. (1996). Labor Force Participation and Health: A Cohort Comparison of older Male Workers. Social Science Quarterly, 70, 449-467.

Ndunisi, N. O., Jantan, M., \& Ricardson, S. (2001). Is The Technology Acceptance Model Valid For Entrepreneurs? Model Testing and Examining Usage Determinants. Asian Academy of Management Journal, 6(2), 40-46.

Page, C. A. (2000). Applied research design for business and management. Sydney: McGraw Hill Companies, Inc. 
Pearlin, L. I., \& Schooler, C. (1978). The structure of coping, Journal of health and social behavior, 19(1), 2-21. http://dx.doi.org/10.2307/2136319

Rashed. A. A. (2001). The Effects of Personal Characteristics on Job Satisfaction: A Study among Male Managers in the Kuwait Oil Industry. International Journal of Commerce \& Management, 11(3), 91-111.

Roberts, J. A., Lapidus, R. A., \& Chonko, L. B. (1997). Salesperson and Stress: The Moderating Role of Locus of Control on Work Stressors and Felt Stress. Journal of Marketing Theory and Practice, 5(3), 93-108.

Schafer, W. (2000). Stress management for wellness, $4^{\text {th }}$ Edition. Belmont, CA: Thomson.

Sekaran, U. (2000). Research Methods for Business. $3^{\text {rd }}$ Edition, New York: John Wiley \& Sons Inc.

Sethi, A. S., \& Schuler, R. S. (1984). Handbook of organizational stress coping strategies. Cambridge, MA: Ballinger.

Tashakkori, A., \& Teddlie, C. (2003). Handbook of Mixed Methods in Social \& Behavioral Research. SAGE Publications, 2003 - Social Science.

Wiggins, P. A. (1994). Marital Satisfaction of Aging couples during Retirement. Masters Treatise, Port Elizabeth: University of Port Elizabeth.

Williams, S., \& Cooper, L. (2002). Managing Workplace Stress. Great Britain: John Wiley \& Sons, Ltd.

\section{(c) $)$ EY}

This work is licensed under a Creative Commons Attribution 3.0 License. 